\title{
OTR14 Pesquisa e desenvolvimento de formulações para proteção de protoxinas de Bacillus e outras bactérias esporuladas entomopatogênicas
}

Vera Cristina Pessoa de Lima $^{1}$, Adriana Marcus Vivoni ${ }^{1}$, Leon Rabinovitch ${ }^{1}$, Maria Alice Varjal de Mello Santos², Ricardo Tadeu Lopes $^{3}$

1 Instituto Oswaldo Cruz, Fiocruz, Rio de Janeiro, RJ

${ }^{2}$ Centro de Pesquisa Aggeu Magalhães - CPqAM, Fiocruz, PE

${ }^{3}$ Universidade Federal do Rio de Janeiro - UFRJ

Introdução: Bacillus e Gêneros correlatos apresentam espécies que são larvicidas, particularmente de mosquitos vetores de doenças. Alguns sorovares produzem protoxinas as quais os insetos transformam em estruturas químicas altamente tóxicas para si próprios. Com base nesse conhecimento e achado, alguns sorovares de Bacillus thuringiensis e de Lysinibacillus sphaericus (ex $B$. sphaericus) são usados em preparações inseticidas.

Objetivo: Desenvolver preparações à base de L. sphaericus altamente entomotóxico, obter a toxina ativa e isenta de esporos viáveis, utilizar radiação ionizante para se alcançar a inativação exclusiva dos esporos.

Metodologia: A cepa de L. sphaericus 2362 foi semeada em Ágar Nutriente com Metais e incubada a $33^{\circ} \mathrm{C}$ até $80 \%$ de esporulação. Em seguida, o induto bacteriano foi transferido para Erleymeyer contendo $35 \mathrm{~mL}$ de $\mathrm{NaCl}$ a $0,85 \%$ onde ficou sob agitação por $2 \mathrm{~h}$. Desta suspensão, colocou-se $6 \mathrm{~mL}$ em 5 tubos para a realização da Termorresistência a $70^{\circ} \mathrm{C}$ por $15 \mathrm{~min}$. As diluições foram realizadas na proporção de 1:10 e delas plaqueadas $100 \mu \mathrm{L}$ em placas de Petri contendo Ágar Plate Count. Da suspensão-mãe, tomou-se $50 \mu \mathrm{L}$ do inóculo e transferiu-se para 4 Erleymeyer contendo $100 \mathrm{~mL}$ de Caldo NYSM, onde ficou sob agitação a $33^{\circ} \mathrm{C}$ até $80 \%$ de esporulação. Transferiu-se a suspensão para 6 tubos Falcon e centrifugou-se até "pellet" firme, que foi lavado com $1 \mathrm{~mL}$ de água destilada e recentrifugado. Suspendeu-se o "pellet" em $5 \mathrm{~mL}$ de salina e destribuiuse em 12 Eppendorf com $500 \mu \mathrm{L}$ cada, e novamente centrifugou-se. Este processo se repetiu várias vezes quando se separou 6 Eppendorf para receberem respectivamente as doses em kgy $(5,0 ; 7,5 ; 10 ; 12,5 ; 15 ; 17,5$ e 20) com Co60.

Resultados: Após a irradiação ficou demonstrado que a dose de 20 kgy apresentou melhor resultado quanto à inativação de esporo com a preservação da toxina. As amostras foram separadas em frascos estéreis em biomassa irradiada e não irradiada, onde foram secas, pesadas e enviadas ao CPqAM- PE para a determinação de potência UTI. Para o ensaio qualitativo do tipo "mata não mata" utilizou-se larvas L3 jovens de Culex quinquefasciatus. O mesmo processo foi feito para 
a biomassa não irradiada. Os resultados mostraram que as preparações com Larvas tiveram $100 \%$ de mortalidade, como era esperado.

Conclusão: O sistema empregado permitiu separar toxicidade de esporos viáveis.

Palavras-Chave: Bacillus, Radiação lonizante, Co-60, Esporos 